\begin{tabular}{|c|c|c|}
\hline 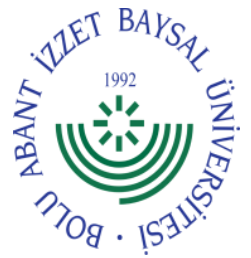 & $\begin{array}{l}\text { International Journal of Agriculture and Wildlife } \\
\text { Science } \\
\text { http://dergipark.org.tr/jiaws }\end{array}$ & 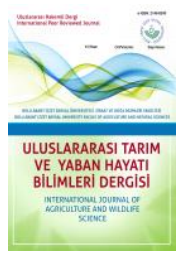 \\
\hline
\end{tabular}

Research Article

\title{
Population Density of Bangasternus planifrons in Eskişehir Safflower Cultivation Areas
}

\author{
Cenk Yücel ${ }^{*}$ iD , Aydemir Barış \\ Plant Protection Central Research Institute, Ankara, Turkey \\ Received: 16.07.2021 Accepted: 14.09.2021
}

\section{Keywords:}

Bangasternus planifrons, Curculionidae, safflower, distribution, Eskişehir

Abstract. This study was carried out in Eskişehir in 2015 and 2016 to determine the prevalence and density of Bangasternus planifrons (Brulle, 1832) (Coleoptera: Curculionidae)] in safflower (Carthamus tinctorius L.) cultivation areas. The data obtained from the surveys and samplings carried out in Çifteler, Mahmudiye, Sivrihisar, and Tepebaşı districts, where safflower cultivation was intense, were evaluated. B. planifrons was detected in all of Çifteler, Mahmudiye, Sivrihisar, and Tepebaşı districts in 2015, and the infestation rates were determined as $30.40 \%, 40.40 \%, 44.36 \%$, and $43.40 \%$, respectively. Similar to the previous year, infestation rates of $15.72 \%, 35.00 \%, 28.92 \%$, and $30.13 \%$ were determined, respectively. In the districts of Çifteler, Mahmudiye, Sivrihisar, and Tepebaşı, the density of the pest in 2015 was 4.67, 4.16, 5.68, and 3.23 adult individuals/plants while it was 5.16, 3.70, 7.44 and 5.66 adult individuals/plants in 2016. It has been determined by our study that larvae cause damage by feeding on newly formed seeds and economic loss in the safflower.
\end{abstract}

\section{Eskişehir Aspir Alanlarında Bangasternus planifrons'un Populasyonun Yoğunluğu}

\section{Anahtar kelimeler:} Bangasternus, Curculionidae, aspir, yaygınlık, Eskişehir
Özet. Bu çalışma, Bangasternus planifrons (Brulle) (Coleoptera: Curculionidae)]'nin aspir (Carthamus tinctorius L.) ekiliş alanlarındaki yaygınlık ve yoğunluğunu belirlemek amacıyla Eskişehir ilinde 2015 ve 2016 yıllarında gerçekleştirilmiştir. Aspir ekilişinin yoğun olarak yapıldığı Çifteler, Mahmudiye, Sivrihisar ve Tepebaşı ilçelerinde yapılan sürvey ve örneklemelerden elde edilen veriler değerlendirilmiştir. $B$. planifrons, 2015 yılında Çifteler, Mahmudiye, Sivrihisar ve Tepebaşı ilçelerinin tamamında tespit edilmiş ve sırasıyla \%30.40, 40.40, 44.36 ve 43.40 bulaşma oranları belirlenmiştir. Zararlının bir önceki yıla benzer şekilde 2016 yılında da sırasıyla \%15.72, 35.00, 28.92 ve 30.13 bulaşma oranları saptanmıştır. Çifteler, Mahmudiye, Sivrihisar ve Tepebaşı ilçelerinde zararlını 2015 yılındaki yoğunluğu sırasıyla ortalama 4.67, 4.16, 5.68 ve 3.23 adet ergin birey/bitki; 2016 yılında ise sırasılyla ortalama 5.16, 3.70, 7.44 ve 5.66 adet ergin birey/bitki olarak saptanmıştır. Larvalarının yeni oluşan tohumlarda beslenmesi ile zarar oluşturduğu ve üründe ekonomik kayba neden olduğu çalışmamız ile saptanmıştır. 


\section{INTRODUCTION}

Safflower (Carthamus tinctorius L.), an annual oily plant that contains $30-50 \%$ oil in its seeds, whose oil can be used in the production of biodiesel, and whose pulp is used as animal feed. Although safflower is an important oil plant for both cooking oil and biodiesel production, it has an important advantage that it does not compete with other oilseed plants due to its high drought resistance. Safflower can be easily grown in arid conditions compared to other oilseed plants such as sunflower, soybean, rapeseed and has increased in importance in recent years in terms of climate changes (Köse, 2017). About $60 \%$ of the oil consumed in Turkey is imported. The limited production of existing oil plants and the gradual decrease of irrigable agricultural areas have increased the cultivation of drought-resistant plants such as safflower as an alternative in recent years. Due to the supports given to encourage agricultural production, the safflower cultivation area reached 151.150 da and 21.325 tons in 2020 (Anonymous, 2021).

While 8 species of Bangasternus are known in the Palearctic region (Hoffmann, 1954), 3 species are known in our country (Lodos et al., 1978 and 2003). Bangasternus spp. (Coleoptera: Curculionidae) specialized to Centaurea species in the Asteraceae family. It is widely used in the biological control of Centaurea species in studies conducted around the world. It has been determined that Bangasternus orientalis (Capiomont) feeds inside the flower capsule of Centaurea solstitialis L. and damages its seeds (Maddox et al., 1991). Sobhian et al. (1992a), stated that $B$. orientalis was fed with yellow star-thistle in their laboratory and field trials for the control of yellow star-thistle. Sobhian et al. (1992b), stated that the white knapweed (Centaurea diffusa Lam.) plant was infected with $B$. fausti at a rate of $72-100 \%$. Although it has been stated that the pest was used as a biological control agent in studies, Damkacı (2013) reported for the first time that B. planifrons (Brulle) was a pest in safflower fields in Turkey. Sert and Çağatay (1994) detected the B. orientalis (Capiomont) in Kalecik, Çubuk, and Güdül districts of Ankara province. B. planifrons (Brulle) is an important pest of safflower in our country. B. planifrons feeds on the green parts and seed pods of the plant, causing yield and quality loss in the product (Yücel et al., 2019).

This study was carried out in 2015 and 2016 to determine the prevalence, infestation, and damage of $B$. planifrons causing a decrease in seed quality and quantity in the safflower plant, whose cultivation area has increased in our country in recent years, in Eskişehir.

\section{MATERIAL AND METHOD}

The survey and sampling studies were carried out in May-June 2015 and 2016 to determine the prevalence, infestation rates, and density of Bangasternus planifrons (Coleoptera: Curculionidae) in the districts where safflower cultivation was carried out in Eskişehir. Sampling areas were given in Table 1.

Table 1. Sampling areas and location information in Eskişehir province.

Çizelge 1. Eskişehir ilinde örnekleme yapılan alanlar ve lokasyon bilgileri.

\begin{tabular}{|c|c|c|}
\hline Year & 2015 & 2016 \\
\hline Çifteler & 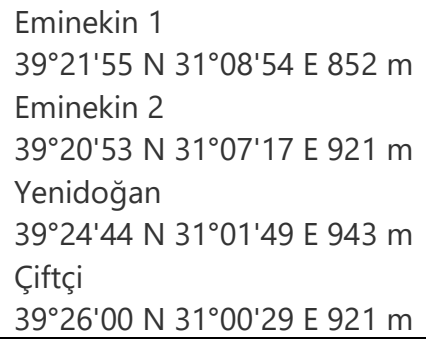 & $\begin{array}{l}\text { Belpınar } \\
39^{\circ} 17^{\prime} 49 \text { N 310.04'02 E } 958 \text { m }\end{array}$ \\
\hline Mahmudiye & 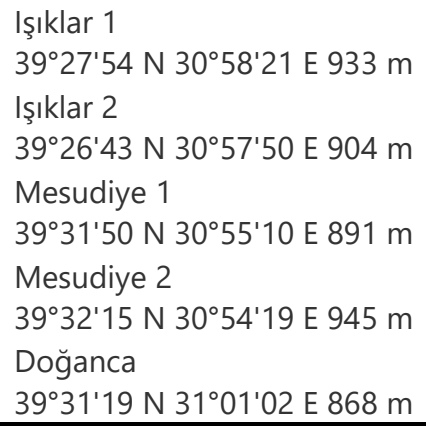 & 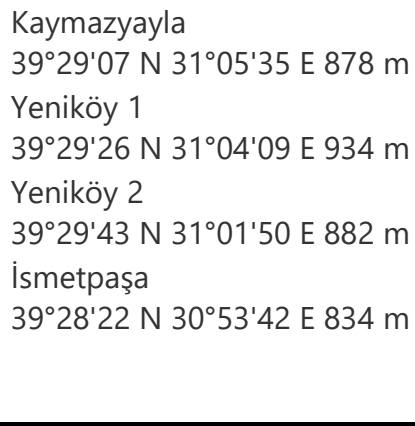 \\
\hline
\end{tabular}




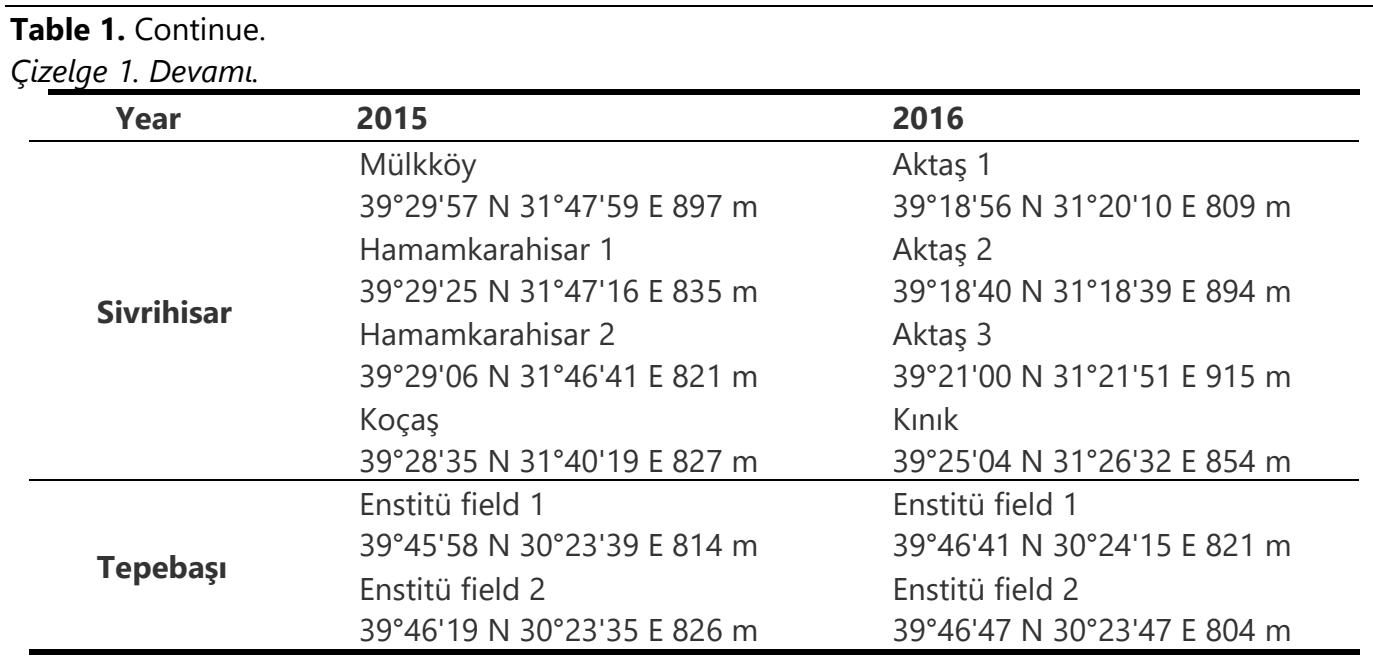

To determine the infestation rate of $B$. planifrons in the field, 100 plants were sampled from 10 different points on the calculation of 10 da by moving in a zigzag pattern in the direction of the diagonals in the field. The number of plants examined was increased according to the size of the sampled site (Jarvis and Guthrie, 1987). The average number of adults per plant was determined by counting the $B$. planifrons adults detected in the sampling plants. The field infestation rate was calculated according to the following formula:

$$
\text { Field infestation rate }=(\text { Number of Infested Plants/Total Plants }) \times 100
$$

Pest prevalence was determined as present or absent, taking into account the field size and not considering the density of the pest in the field. The prevalence rate was calculated according to the following formula:

$$
\text { Prevalence rate }=(\text { Infested area/Total area }) \times 100
$$

The provincial and district infestation rate of the pest was calculated by taking the weighted average. The infestation rate calculated for each field was multiplied by that field size and the multiplying obtained for all fields examined were summed. The infestation rate in the province was calculated by dividing this total by the maximum infestation probability (Bora and Karaca, 1970).

\section{RESULTS AND DISCUSSION}

To determine the prevalence and density of Bangasternus planifrons, field controls were started in the Çifteler, Mahmudiye, Sivrihisar, and Tepebaşı districts of Eskişehir when the safflower plant had 6-8 leaves. According the weather climatic condition based on the district, the adults overwintered between 15-21 May in 2015. Moreover, adults switch to the plant and switch to feeding when the weather warms up. The pest causes damage, especially by feeding on the fresh shoots and leaves of the plant. As a result of feeding, necrosis occurs on the leaves and causes complete drying of the leaves in the following period.

In the sampling in 2015, it was determined that the districts of Çifteler, Mahmudiye, Sivrihisar, and Tepebaşı were $100 \%$ infested with the pest and reached $30.40 \%, 40.40 \%, 44.36 \%$, and $43.40 \%$ infestation rates, respectively. There was an average of $4.67,4.16,5.68$, and 3.23 adult/infected plants in the areas where it was infested, respectively (Figure 1).

In the samplings of 2016, all areas were infested with pests similar to the previous year. It has been observed that chemical control was carried out against the pest in some areas, therefore the prevalence was decreased relatively compared to the previous year. It was determined that infestation rates of the pest were $15.72 \%, 35.00 \%$, $28.92 \%$, and $30.13 \%$, respectively, in Çifteler, Mahmudiye, Sivrihisar, and Tepebaşı districts. There was an average of $5.16,3.70,7.44$, and 5.66 adult/infected plants in the infested areas, respectively (Figure 2). 


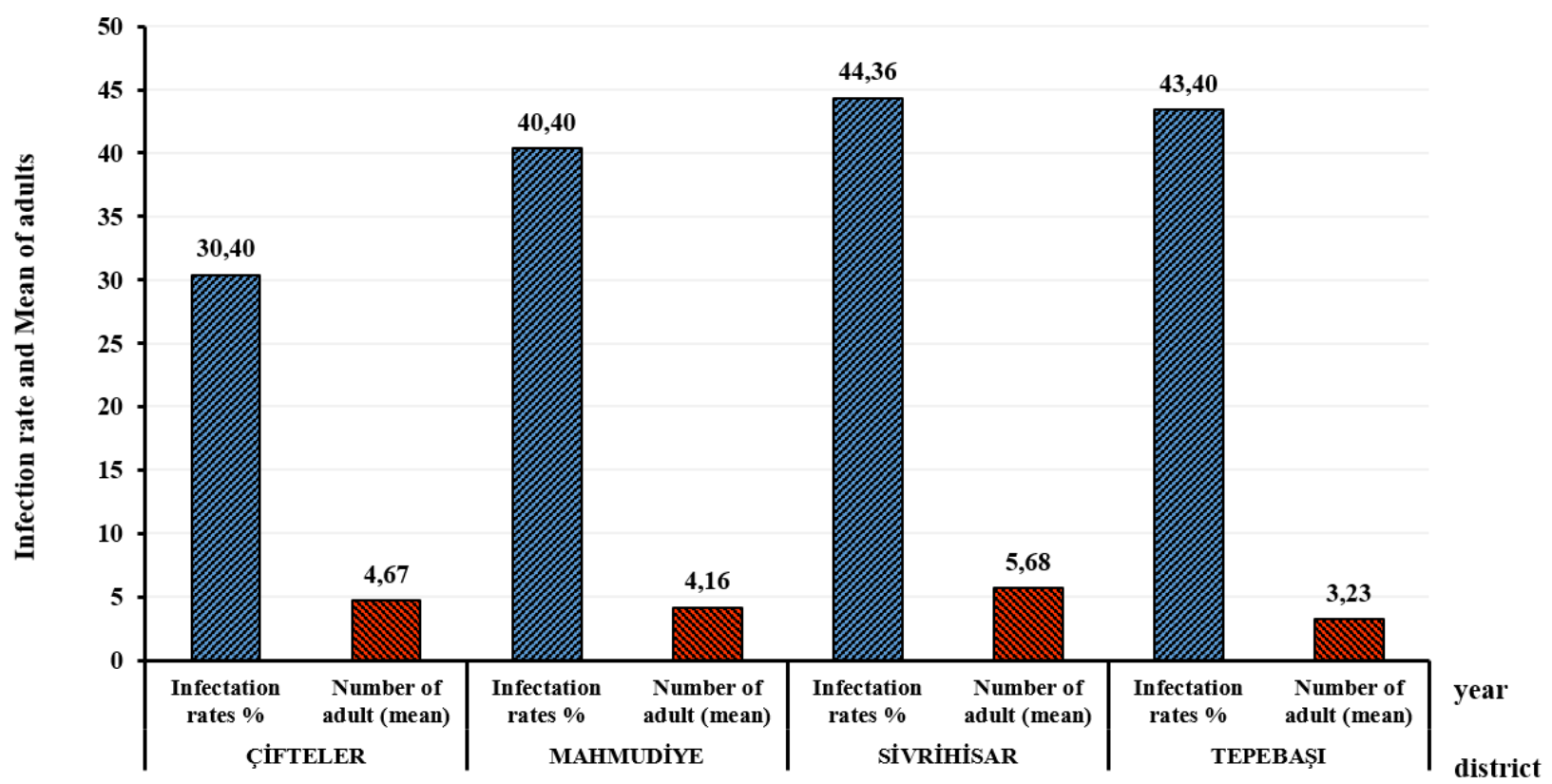

Figure 1. Infestation rates and mean adult individuals (per plant) of Bangasternus planifrons in safflower fields in Eskişehir in 2015 by districts.

Şekil 1. Eskişehir ili aspir alanlarında Bangasternus planifrons'un 2015 yılında ilçelere göre bulaşma oranları ve bitki başına düşen ortalama ergin sayıları.

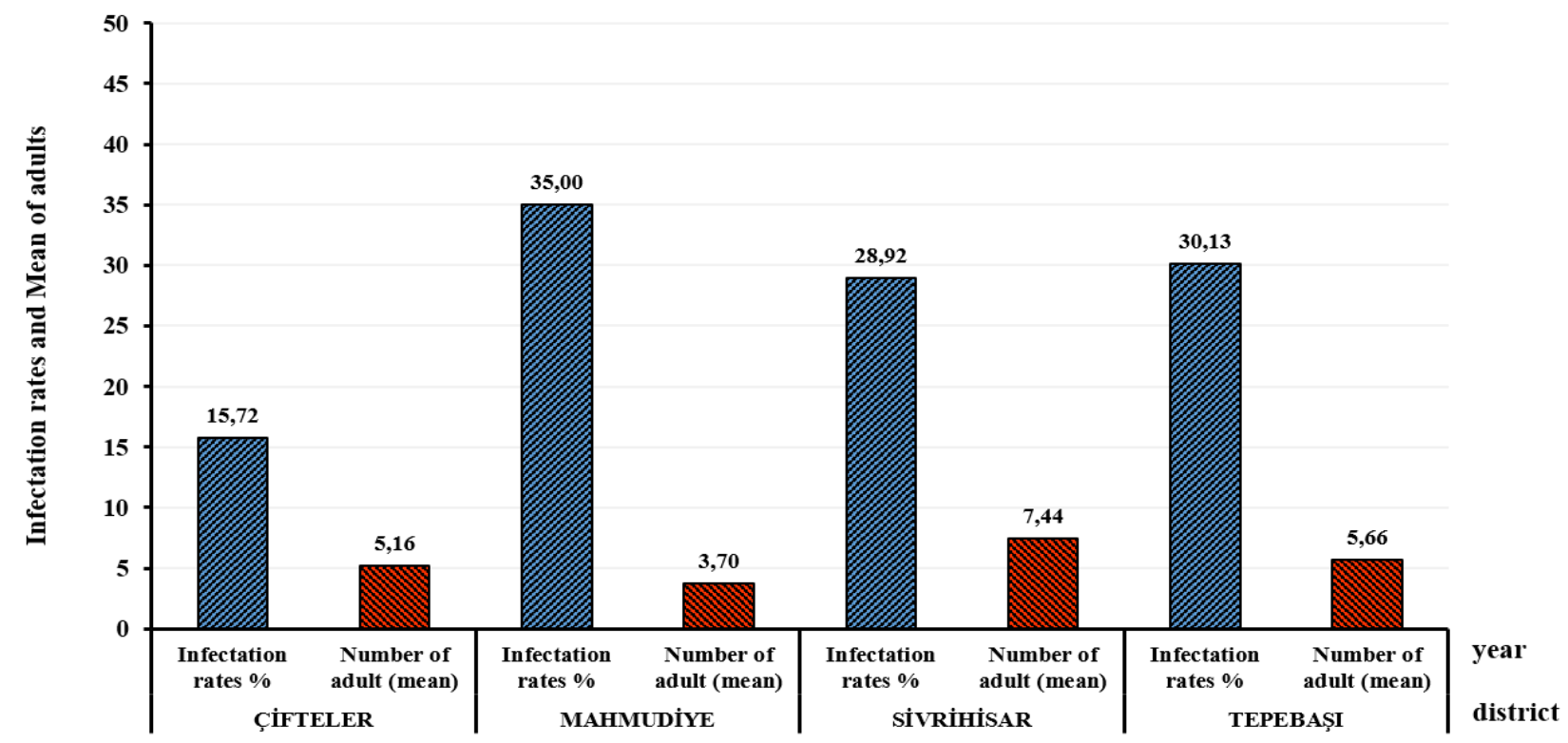

Figure 2. Infestation rates and mean adult individuals (per plant) of Bangasternus planifrons in safflower fields in Eskişehir in 2016 by districts.

Şekil 2. Eskişehir ili aspir alanlarında Bangasternus planifrons'un 2016 yılında ilçelere göre bulaşma oranları ve bitki başına düşen ortalama ergin sayıları.

As a result of the two-year survey, it was determined that all districts (Çifteler, Mahmudiye, Sivrihisar, and Tepebaşı) of Eskişehir were $100 \%$ infested with the pest. Overwintered adults started to appear in mid-May, caused damage to the green parts of the safflower plant, especially to the fresh shoot leaves, in a period of 3540 days until mid-June. Adults in infested plants mate and lay eggs in the newly formed seed capsule. In the study, the prevalence rate in Eskişehir in 2015 was 100\%, the infestation rate was 39.90\%, and the mean number 
of adults in the infested plants was determined as 4.57 per plant. In the second year of the study, the prevalence rate was $100 \%$, the infestation rate was $28.98 \%$, and the mean number of adults in the infested plants was 4.29 .

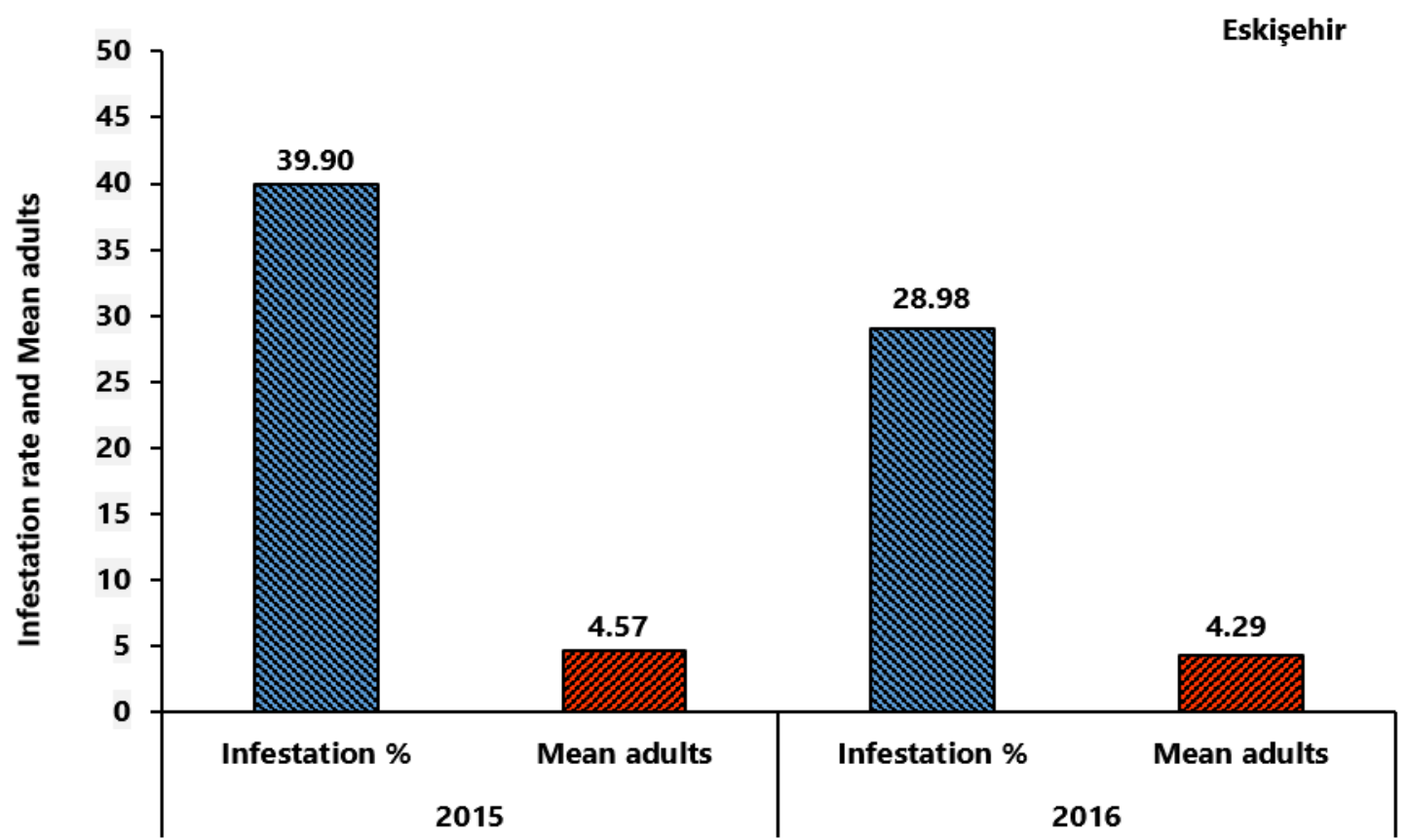

Figure 3. Infestation rates and mean adult individuals (per plant) of Bangasternus planifrons in the safflower areas of Eskişehir province in 2015 and 2016.

Şekil 3. Eskişehir ili aspir alanlarında 2015 ve 2016 yıllarında Bangasternus planifrons'un bulaşma oranları ve bitki başına düşen ortalama ergin sayıları.

Bangasternus spp. (Coleoptera: Curculionidae) is specialized especially for Centaurea species within the family of Asteraceae. It is widely used in the biological control of Centaurea species in studies conducted around the world. It has been determined that B. orientalis (Capiomont) feeds inside the flower capsule of Centaurea solstitialis L. and damages its seeds (Maddox et al., 1991). Although it has been stated that the pest was used as a biological control agent in studies conducted abroad, Damkacl (2013) stated that Bangasternus planifrons (Brulle) was a pest in safflower fields for the first time in a study conducted in Konya in 2013. In addition, Yücel et al. (2019) determined that B. planifrons is an important pest in the safflower fields of Ankara province and feeds on the green parts and flower capsules, causing economic loss. In our study, the pest was common in Eskişehir, where climatic conditions were similar to that of Konya and Ankara, and it caused economic damage.

\section{CONCLUSION}

Many factors cause losses in the products obtained as a result of agricultural activities. One of the important biotic factors is insects. Characteristics such as yield, oil rate, and oil yield in safflower production are highly affected by insect damage. Bangasternus planifrons, one of the most important pests of safflower, feeding on safflower causes a decrease in product quality and quantity. There is a need for studies on the control of the pest, which is a problem for safflower growers in Eskişehir because the studies conducted in our country are limited and it causes economic damage.

\section{CONFLICT OF INTEREST}

Authors have declared no conflict of interest.

\section{DECLARATION OF AUTHOR CONTRIBUTION}

Authors declares the contribution of the authors is equal. 


\section{ACKNOWLEDGMENT}

The authors would like to thank the Plant Protection Central Research Institute, Ankara, Turkey, for the support provided throughout the research work.

\section{REFERENCES}

Anonymous. (2021). Turkish statistical institute. https://biruni.tuik.gov.tr/medas/?kn=92\&locale=tr. Access date: 20 Temmuz 2021.

Bora, T., \& Karaca, i. (1970). Measurement of Disease and Damage in Cultivated Plants. Ege University, Faculty of Agriculture Auxiliary Textbook 167, Turkey.

Damkacı, S. A. (2013). Insect pests of safflower (Carthamus tinctorius: Asteraceae) and their predators in Konya province. Master of Science, Selcuk University, Institute of Science, Konya.

Hoffmann, A. (1954). Fauna de France, Coleopteres, Curculionides. Deuxieme Partie, 59, France.

Jarvis, J. L., \& Guthrie, W. D. (1987). Ecological studies of the European corn borer (Lepidoptera: Pyralidae) in Boone County, lowa. Environmental Entomology, 16, 50-58.

Köse, A. (2017). Agricultural performances of some safflower (Carthamus tinctorius L.) varieties under Eskisehir conditions. Selcuk Journal of Agriculture and Food Science, 31(2), 1-7.

Lodos, N., Önder, F., Pehlivan, E., \& Atalay, R. (1978). The Study of the Harmful Insects Fauna of Marmara and Aegean Regions [(Curculionidae, Scarabaeidae (Coleoptera); Pentatomidae, Lygaeidae, Miridae (Heteroptera)]. T.C. Gıda, Tarım ve Hayvancilık Bakanlığı. Zirai Mücadele Zirai Karantina Genel Müdürlüğü Yayınları, Turkey.

Lodos, N., Önder, F., Pehlivan, E., Atalay, R., Erkin, E., Karsavuran, Y., Tezcan S., \& Aksoy, S. (2003). Faunistic Studies on Curculionidae (Coleoptera) of Western Black Sea, Central Anatolia and Mediterranean Regions of Turkey. Meta Basım Matbaacılık Hizmetleri, Turkey.

Maddox, D. M., Joley, D. B., Mayfield, A., \& Mackey, B. E. (1991). Impact of Bangasternus orientalis (Coleoptera: Curculionidae) on achene production of Centaurea solstitialis (Asterales: Asteraceae) at a low and high elevation site in California. Environmental Entomology, 20(1), 335-337.

Sert, O., \& Çağatay, N. (1994). Systematic studies on the some species of the Genera Sitona, Bangasternus and Larinus (Coleoptera: Curcuiionidae). Turkish Journal of Entomology, 18(4), 223-236.

Sobhian, R., Campobasso, G., \& Dunn, P. H. (1992a). Contribution to the biology of Bangasternus orientalis Capiomont (Col., Curculionidae). Journal of Applied Entomology, 113(1-5), 93-102.

Sobhian, R., Campobasso, G., \& Dunn, P. H. (1992b). A contribution to the biology of Bangasternus fausti (Col.: Curculionidae), a potential biological control agent of diffuse knapweed, Centaurea diffusa, and its effect on the host plant. Entomophaga, 37(2), 171-179.

Yücel, C., Barış, A., \& Ayten, S. (2019). Determination of the distribution and density of Seedhead weevil [Bangasternus planifrons (Brulle) (Coleoptera: Curculionidae) harmfull on safflower in Ankara province. Anadolu Journal of Agricultural Sciences, 34(1), 35-39. 